\title{
ON THE FIRST BUFFON EDITION EVER PUBLISHED IN THE NETHERLANDS
}

\author{
by \\ P. TUIJN \\ Artis-Bibliotheek, Universiteit van Amsterdam
}

One of the more recent acquisitions of the ArtisBibliotheek is an interesting edition of Buffon's Histoire Naturelle. It is a copy of the edition by Pieter de Hondt in the Hague in 1750 (Genet-Varcin et Roger, 1954, nr. 148; Nissen, 1966, nr. 677; TujJ, 1967, Note II, nr. 1). As far as I have been able to ascertain, no copy of this edition has thusfar been in the possession of any dutch public library. Our copy, with book-plates of Grandjean d'Alteville (Rolland, 1954 , p. 144) and André Gaultry, is composed of 3 volumes $4^{\circ}$ bound together in leather. In connection with my supposition (l.c.) that no further volumes of this edition would have been published and that Schneider possibly would have taken over, now the opportunity offers itself to compare the de Hondt and Schneider editions and to look for differences between these editions and the original Paris edition, the first three volumes whereof appeared in 1749 .

\section{EDITION P. DE HONDT, THE HAGUE, 1750.}

TOME PREMIER.

1. No half-title.

2. On the title-page (fig. 1) "Naturelle", "Cabinet du Roy", "Tome Premier", "A La Haye" and "MDCCL" are printed in red. One notices that Buffon is not mentioned, neither is his name on the titlepage of the Paris edition.

The engraver Jacobus van der Schley (Amsterdam 1715-1775) is mainly known for his book-illustrations and vignettes. From his twelfth year on he received instructions from Bernard Picart (Paris 11.VI.1673 Amsterdam 8.V.1733) who settled in Amsterdam about 1710. The surname "Le Romain" was given to his father who had been working in Rome for a considerable time. It is remarkable that de Hondt, as opposed to recent biographical dictionaries, names the father Etienne Picart and not the son Bernard as van der Schley's teacher. As the father died in
Amsterdam on november twelfth 1721, he could hardly have influenced van der Schley, who was a six-year-old boy at the time.

3. A dedication (Epitre) of 4 pages follows, written by Pierre de Hondt to the "Comte de Bruhl" who is submissively flattered in terms like "un des plus fidelles et des plus zèlez Partisans de la Republique des Lettres". This Count of Brühl (Weissenfels 13. VII.1700 - Dresden 28.X.1763) was prime minister under August III, King of Poland and Elector of Saxony. His library, which comprised 62,000 books, formed at the time the main constituent of the Royal Library in Dresden. Whether the fame of this collection was the reason for the dedication by de Hondt, who possibly hoped to make its owner an important customer, or whether there were other considerations I don't know.

The dedication is preceded by a vignette (fig. 2) by J. v. d. Schley showing the coat of arms of the von Brühl's (RIETstap, 1884, vol. 1, 316). In the Paris edition a short dedication is found to the King written by Buffon and Daubenton.

4. A "Préface" of 3 pages printed in 2 columns follows, giving a detailed survey of the planned Paris edition: 15 volumes $4^{\circ}$, treating also of birds, invertebrates and plants (this while eventually this Paris edition in 1804 numbered 44 volumes including the supplements of La Cépède, whereas neither invertebrates nor plants are dealt with in these volumes). In this introduction Buffon and Daubenton are mentioned as the authors. The "Préface" is based on the prospectus published in Paris in Journal des Sçavans 1748 (Heilbrun, 1952; Genet-Varcin et ROGER, l.c.), as is apparent from an "Addition des Editeurs Hollandais".

The first volume would according to the prospectus open with: "une préface dans la quelle on donne un détail Historique sur l'établissement \& l'utilité du Jardin Royal, \& en particulier sur celle du Cabinet 
d'Histoire Naturelle, sur les soins qu'on s'est donné pour le former, sur les graces particulières que le Roy a répandues sur cet établissement", but this introduction has not been published in any edition known to me. It is remarkable to note that a considerable period passed between printing and publishing the first volumes and apparently some alterations in the text were made. In the introduction to the sixth volume of the Paris edition (published in 1756) is stated that the first volume was printed in 1746, the second in 1747 , but both were actually published not before 1749 together with the third volume (Nissen, l.c., nr. 672). So the "Preface sur l'établissement \& lutilité du Jardin du Roy" was printed probably (for in the Prospectus of 1748 it was still mentioned) but not published after all, as may be seen from the table of contents issued in the Paris Journal des Sçavans of October 1749 at the occasion of the publication of 3 volumes of the Histoire Naturelle. The Amsterdam publisher of the $12^{\circ}$ edition of Journal de Sçavans did not mention the changes (Fevrier 1750, 534) but referred to the prospectus published in his issue of April 1749.

"Les Editeurs Hollandais", not mentioned by name, after reading the Paris prospectus appear to have had the intention to publish the work much cheaper in the Hague with additions: "comme les Cabinets d'Histoire Naturelle qui sont dans ces Provinces contiennent un très grand nombre de morceaux curieux." But after reading the first volume they feared not to be "guidés par le même génie supérieur qui brille dans tout ce livre", whereupon they decided in order not to impair the uniformity of Buffon's work to publish the additions separately. As far as I know this never happened and according to the publisher's list of P. de Hondt (to be found in volume 10 (1753) of l'Histoire Générale des Voyages) they must have been more selfconfident three years later when volume 4 of lHistoire Naturelle was announced: "qui contiendra des Pièces qui ne se trouvent pas dans l'Edition de Paris". Nowhere have I been able to find this fourth volume. In later Buffon editions published in the Netherlands, additions written by Allamand were included and some of these with observations by Klockner and P. Camper. In an "Avertissement du Libraire" issued in volume 15 of the Schneider edition the differences and alterations as compared with the Paris edition are discussed volume by volume. Also in this article, the announcement is made that the first part of $l$ Histoire Naturelle des Oiseaux is being printed (1771) and will be sold for half the price of the Paris edition. As the first volume of the Oiseaux was not published until 1796 and not by Schneider but by Blussé at Dordrecht, Schneider apparently has not been able to carry out his plans.

5. Publisher's List of de Hondt covering 1 page. In the field of natural history one finds two editions of IHistoire Naturelle des Oiseaux par M. E. Albin, $3 \mathrm{vol}$. in $4^{\circ}$ and L'art de faire éclorre \& délever en toute Saison des Oiseaux Domestiques etc. par Mr. de Reaumur, 2 vol. in $12^{\circ}$.

6. "Table de ce qui est contenu dans ce volume", 2 pages.

7. The text of 222 pages, printed in two columns, is wholly in accordance with the text of the Paris edition. The Paris edition, however, is printed on full page. There are 3 vignettes, 2 engravings and 2 maps all signed "J. v. Schley sculp." but these are undoubtedly copies of the illustrations in the Paris edition signed by different artists.

\section{TOME SECOND.}

8. No title page.

9. No table of contents.

10. The text of the 228 pages printed in 2 columns is identical with the Paris edition which renders the text full page. 2 Vignettes and Planche VIII are signed: "J. v. Schley sculp." Planches I-VII: "J. van Schley direx". All are copied from the Paris edition.

\section{TOME TROISIÈME.}

11. Title page identical with fig. 1, only "Troisième" instead of "Premier".

12. "Table de ce qui est contenu dans ce volume", 2 pages. In this table of contents "M. Baubenton" (!) is mentioned as the author of the description of the cabinet.

13. The text of 203 pages printed in 2 columns is identical with that of the Paris edition which renders it full page. There is 1 vignette signed "J. v. Schley sculp." and 17 plates signed "J. v. Schley direx". As Planche $X$ bears a wrong pagenumber $-49-$ it is bound between Planches III and IV, whereas the figures on Planche $X$ are not discussed before p. 92 and Planche IX is. followed now by Planche XI. Furthermore Planche VII is wrongly placed before Planche VI and Planche XVII without reason precedes Planche XVI. In Buffon bibliographies one usually finds the wrong statement made that the third volume contains 14 plates only. This wrong notion has probably been caused by the fact that Planche XIV has been placed last. According to the order of sequence of the text however, Planche XIV 


\section{H I S T O I R E NATURELLE GÉNÉRALE ET PARTICULIĖRE,}

A V E C L A

\section{E S C R I P T I O N}

D U

C A B I N E T D U R O Y.

Ornée de Figures, gravées par J. VANDER SCHLEY, Elève diftingué du Célebre Picart le Romain.

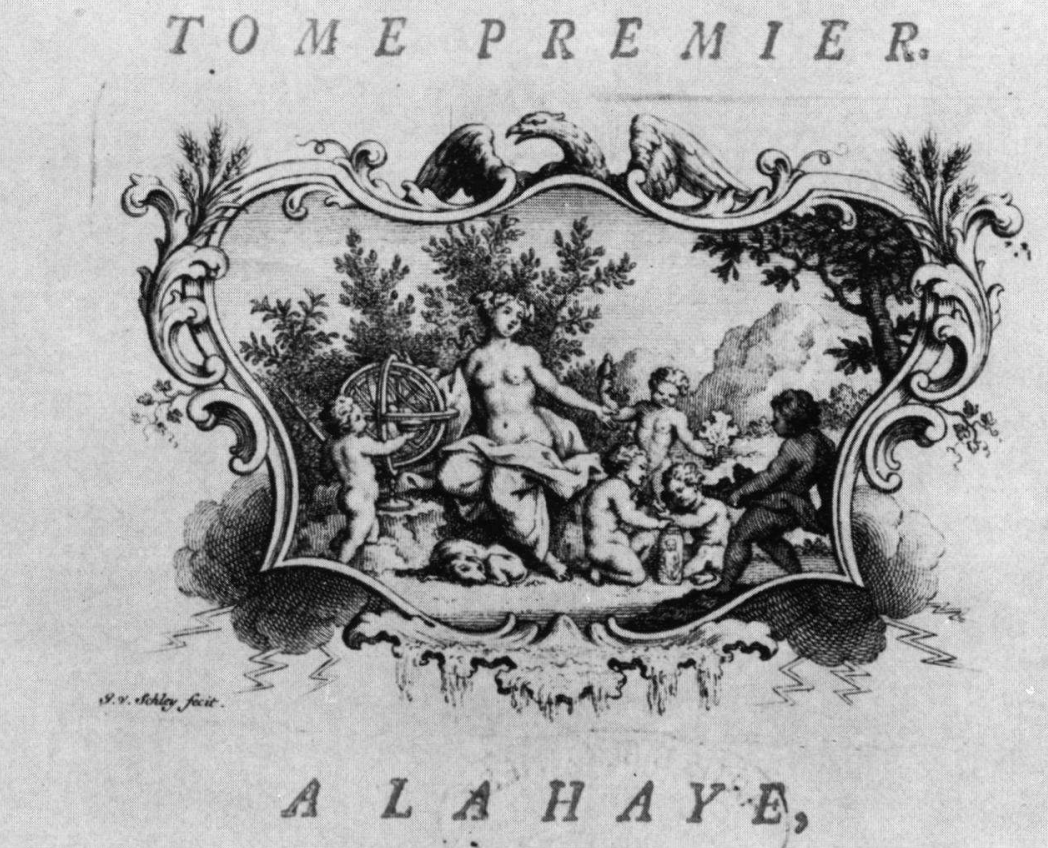

CHEZ PIERRE DE HONDT, $M D C \subset L_{0}$

Fig. 1 


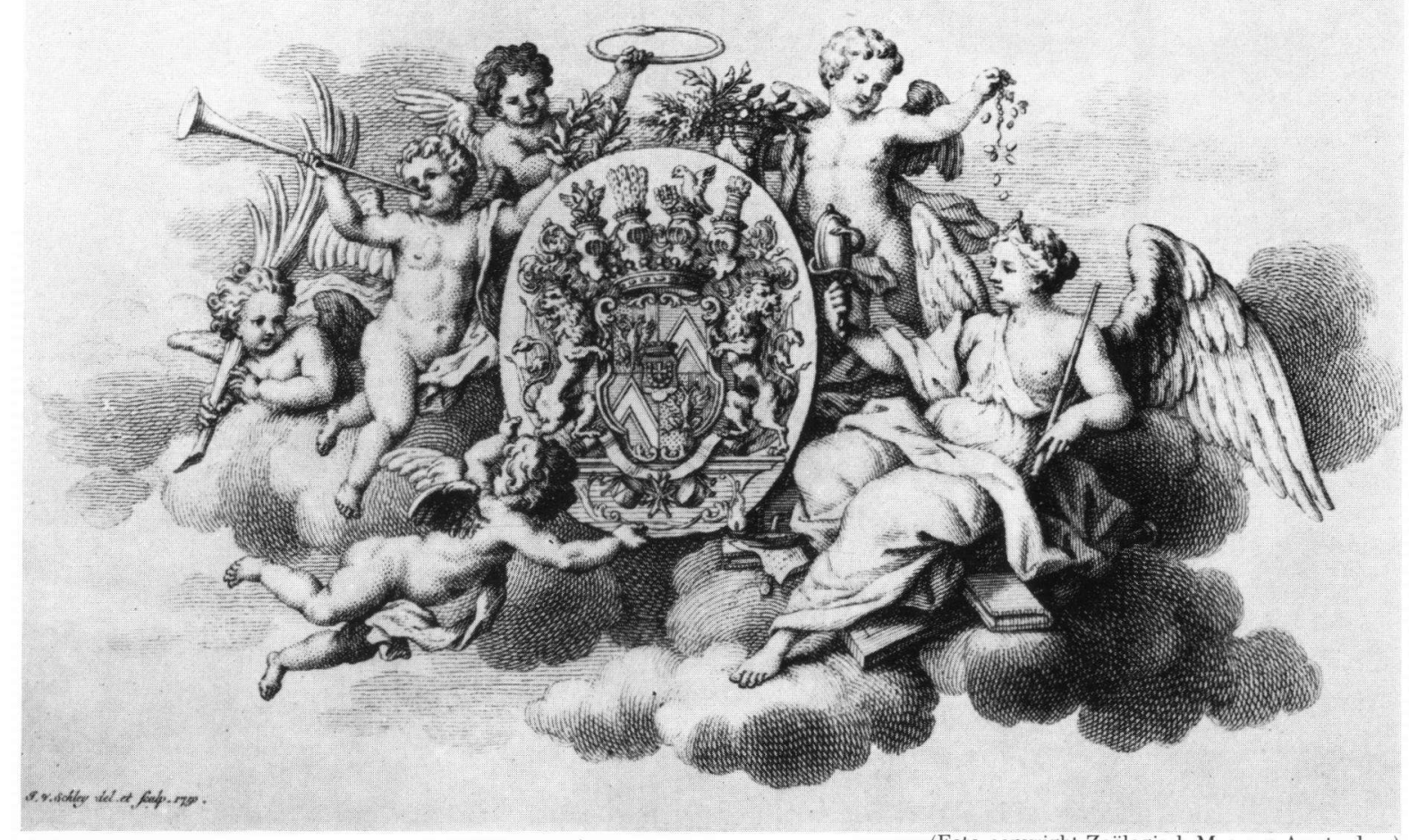

Fig. 2. Coat of arms of von Brïhl.

(Foto-copyright Zoölogisch Museum Amsterdam)

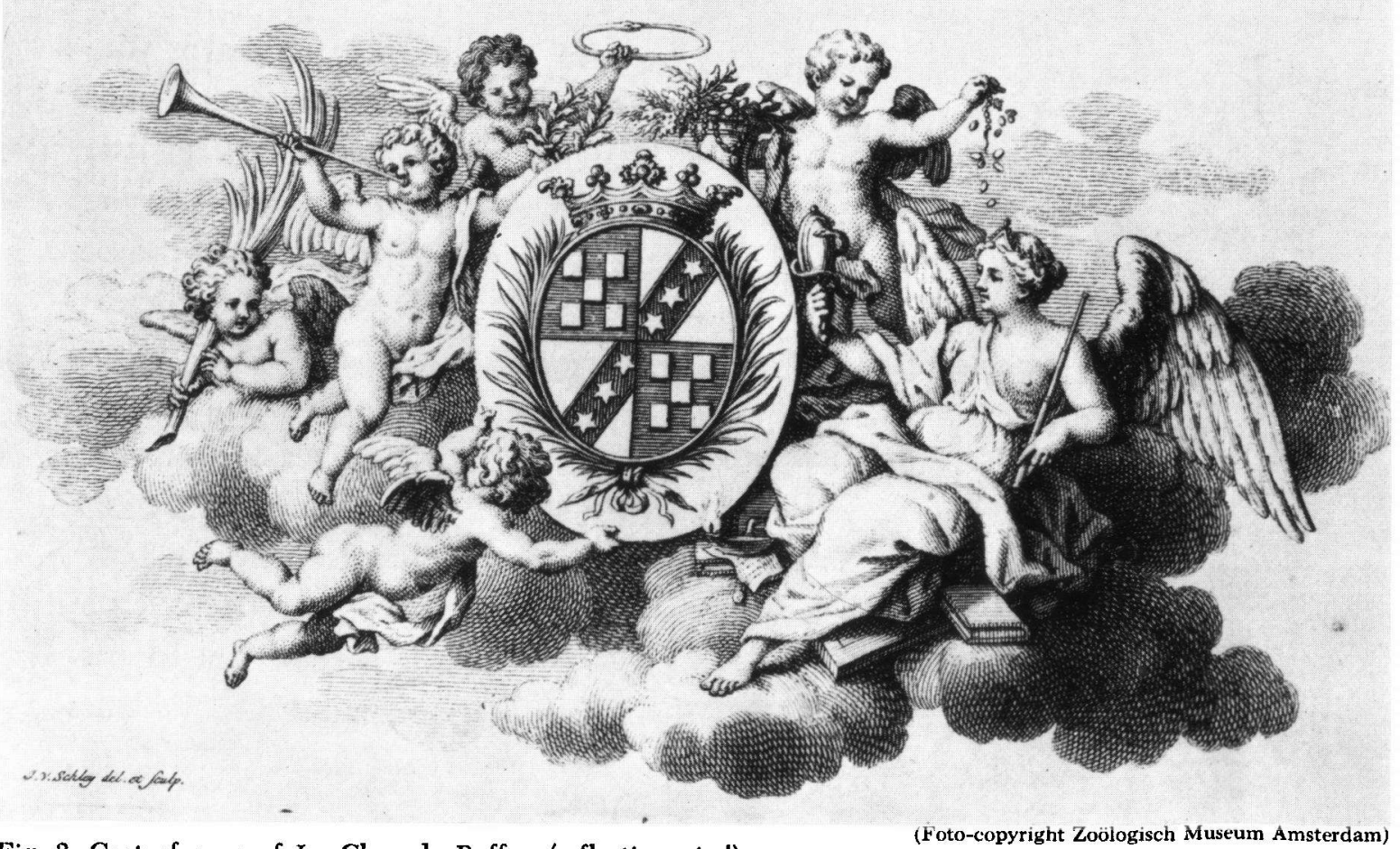

Fig. 3. Coat of arms of Le Clerc de Buffon (reflection-wise!). 
is correctly bound following Planche XVII and facing page 101. Also in the Paris edition Planche XIV is placed last.

14. Finally: "Catalogue des Livres qui se trouvent à la Haye chez Pierre de Hondt", 5 pages. In the field of natural history one finds, besides the books mentioned above (see 5), Gouvernement Admirable de la Republique des Abeilles, avec les moyens d'en tirer grande utilité. A la Haye, 1740, $12^{\circ}$.

EDITION J. H. SCHNEIDER, AMSTERDAM, 1766 (Nissen, l.c., nr. 678; Tuijn, l.c., Note II, nr. 2).

TOME PREMIER.

1. The half-title reads: "Histoire/Naturelle/Générale/et/Particulière/Tome Premier".

2. Titlepage printed in black: "Histoire/Naturelle, /Générale et Particulière,/avec la/Description/du/ Cabinet du Roi./Par Mrs. de Buffon et Daubenton./ Tome Premier./Nouvelle Edition./Vignette signed: "R. Vinkeles. Fecit 1765." 1)/A Amsterdam,/chez J. H. Schneider./MDCCLXVI./Avec privilege de nos seigneurs de Hollande \& de Westfriese."

3. A list of 4 pages with the subscribers and the prices of the first 9 volumes, followed by a somewhat shorter list of subscribers and the prices of the first 8 volumes, comprising again 4 pages. Volumes 1-7 were published in 1766, volume 8 and 9 in 1767 . These lists ought to have been bound in volume 9 and 8 respectively.

4. "Discours prononcé dans l'Académie Françoise, par M. de Buffon" read on Saturday August 25th 1753. This speech was published in Supplement Tome Quatrième (1777) of the Paris edition. It fills 8 pages. It is preceded by a vignette (fig. 3 ) which shows the coat of arms of Buffon (reflectionwise!) 2. Cf. fig. 2: the centre is changed, whereas "J. v. Schley del. et sculp. 1750 " is replaced on a slightly different height by "J. v. Schley del. et sculp.".

1) After volume 15 of this edition had been published, van der Schley's vignette (fig. 1) was again used for the titlepages. This was done on those published by Schneider as well as on those issued by Blussé.

2) Georges Louis Le Clerc, born at Montbard 7.IX.1707, added when he was about 25 years old to his name "de Buffon" after a house and estate of that name which he owned and which was situated a few kms. from Montbard. In 1773 this property was made into a county (Flourens, 1860, LX). He always called himself Buffon and was known by that name. Quarters 1 and 4 ought to have depicted the arms of Le Clerc, each with a ribbon with three stars, 2 and 3 those of Buffon (RIETSTAP, 1884, vol. 1, 432; RolLAND, 1942, vol. 5).
5. "Table de ce qui est contenu dans ce volume". Like the de Hondt edition. From some peculiarities (letters which are not in line etc.) it follows that the same matter is used (see for instance "211" and "Conclusion" at the end of the table of contents).

6. The text is identical with de Hondt's edition.

\section{TOME SECOND.}

7. No halftitle.

8. Titlepage as above (nr. 2) only "Tome Second" instead of "Tome Premier".

9. "Table de ce qui est contenu dans ce volume", 1 page, followed by an "Avis au relieur" concerning the maps which ought to have been bound with the first volume. In the Artis-Bibliotheek-copy they are bound in volume 2 .

10. The text is identical with the de Hondt edition and printed with the same matter (see for instance page 136: the first $\mathbf{E}$ of NATURELLE in the short title at the top of the page is mutilated; page 155: the second 5 of the pagenumber differs from the first).

\section{TOME TROISIÈME.}

11. No halftitle.

12. Titlepage as above (nr. 2) only "Tome Troisième" instead of "Tome Premier".

13. "Table de ce qui est contenu dans ce volume." The text is identical with the de Hondt edition, but the type setting is different (similar to the later volumes of this Schneider edition). "Baubenton" is corrected in "Daubenton".

14. The text is identical with that of the de Hondt edition. Here too Planche $\mathrm{X}$ is bound wrongly (see above in the survey of the de Hondt edition nr. 13).

15. After an unnumbered blank page follows "Description du Squelette humain" covering page 205214 with Planche XVIII, signed "C. F. Fritzsch fec." This article, based on Albinus' Tabulae sceleti \& musculorum corporis humani from which the plate was copied, was obviously printed later. This appears from the finishing sentence: "N.B. On aura soin de placer cette Description du Squelette avec sa figure, à la fin du Troisième volume de cet ouvrage, ce qui se peut faire quand même le volume seroit relié." This instruction was followed in the Artis-Bibliotheek copy; the last section has been glued between page 204 and the fly-leaf.

\section{CONCLUSION.}

The similarities of the editions mentioned above, make it in my opinion very probable that Schneider's 
edition is a continuation of de Hondt's. De Hondt published only 3 volumes for which Schneider probably printed new titlepages and substituted the speech of Buffon for the dedication to von Brühl. Had this not been so, more copies with de Hondt's introductory parts should have been found.

\section{REFERENCES}

AA, A. J. VAN DER, 1852-1878: .Biografisch Woordenboek der Nederlanden. 12 vols. J. J. van Brederode, Haarlem.

Flourens, P., 1860: Des manuscrits de Buffon, avec des facsimile de Buffon et de ses collaborateurs. Garnier Frères, Paris. XCV, 298 p.

Genet-Varcin, E. et J. Roger, 1954: Bibliographie de Buffon. In: Corpus Général des philosophes Français. Auteurs Modernes XLI, 1. Oeuvres philosophiques de Buffon. Presses Universitaires de France, Paris. XXXVII, $616 \mathrm{p}$.

HANKS, LesLey, 1966: Buffon avant l'Histoire Naturelle. Publications de la faculté des lettres et sciences humaines de Paris, Série Recherches XXIV. Presses Universitaires de France, Paris. 324 p.

HeIlbRuN, G., 1952: In: Buffon, série les grands naturalistes français. Muséum National d'Histoire Naturelle, Paris. 244 p.
Nissen, C., 1966: Die zoologische Buchillustration, Lfg. 1. Hiersemann, Stuttgart. 80 p.

RietstaP, J. B., 1884-1887: Armorial Général précédé d'un Dictionnaire des Termes du Blason. 2 vol. Deuxième ed., Gouda, G. B. van Goor Zonen.

Rolland, V. H., 1926-1954: Armorial Général de J. B. Rietstap Suppl. 1-7. La Haye, M. Nijhoff.

THIEME, U., und F. BECKER, 1908-1950: Allgemeines Lexicon der bildenden Künste. Leipzig.

Turs, P., 1967: Historical notes on the Quagga (Equus quagga Gmelin, 1788; Mammalia, Perissodactyla) comprising some remarks on Buffon-editions published in Holland. Bijdr. Dierk. 36, 75-79.

VERWEY, E. DE LA FontaIne, 1934: De illustratie van letterkundige werken in de XVIIIe eeuw. Diss. H. J. Paris, Amsterdam. (8), 192 p. 